\title{
Pemberdayaan Perempuan Kampung Sampora Kelurahan Cibinong Dalam Pengelolaan Sampah Rumah
}

\author{
Enok Rusmanah ${ }^{1)}$ Haqi Fadillah2) Dwi Meyliani Riswanti3) \\ 1)Universitas Pakuan \\ enok.rusmanah@unpak.ac.id
}

\begin{abstract}
Abstrak
Sampah dan pengelolaannya masih menjadi masalah bersama. Diperkirakan 175.000 ton sampah dihasilkan dalam sehari dan didominasi sampah rumah tangga. Berbagai usaha dilakukan untuk menangani masalah sampah termasuk Gerakan Memilah Sampah dari Rumah. Program-program penanganan sampah berbasis masyarakat pun digencarkan seperti Bogor Kabupatenku Green and Clean dengan menciptakan Kampung Ramah Lingkungan (KRL).

Namun pada kenyataannya sampah masih menjadi masalah termasuk di Kampung Sampora, Kelurahan Cibinong, Kabupaten Bogor. Meski memiliki KRL tetapi belum berjalan maksimal. Bahkan masih banyak sampah yang dibuang ke sungai dan pinggir jalan. Hal ini dikarenakan kurangnya pemahaman mengenai sampah, cara pengelolaan dan pemanfaatannya, kurangnya peralatan serta belum terbentuknya lembaga penyalur hasil pengelolaan dan pengendalian sampah seperti bank sampah.

Sejalan dengan program pilah sampah dari rumah, maka pengabdian ini diadakan untuk memberikan penyuluhan, pelatihan, dan pendampingan terhadap masyarakat Kampung Sampora, khususnya melibatkan pemberdayaan ibu rumah tangga sebagai perempuan yang paling banyak beraktifitas di rumah. Hal ini bertujuan untuksharing ilmu mengenai cara pemilahan sampah rumah tangga, pengelolaan dan pemanfaatan sampah dengan berbasis 3R (Reuse, Reduce, Recycle) dan pembentukan bank sampah sebagai wadah untuk menampung hasil dari pemilahan dan pengelolaan sampah. Selanjutnya masyarakat juga dibuatkan alat komposter untuk pengelolaan sampah organik yang mudah digunakan oleh para ibu rumah tangga. Hasilnya, para ibu rumah tangga merasakan tambahan pengetahuan dan bersemangat melakukan pilah sampah dari rumah disertai dengan pemanfaatannya termasuk memaksimalkan bank sampah yang baru terbentuk.
\end{abstract}

Kata Kunci: Sampah Rumah, 3R (Reuse, Reduce, Recycle), Pemberdayaan Perempuan

\footnotetext{
Abstract

Waste and its management are still a common problem. It is estimated that 175,000 tonnes of waste are generated in a day and most of this waste comes from households. Various efforts have been held to address the problem, including the movement to sort waste from home. Community based waste management programs also have been launched including My Bogor Regency Green and Clean which aimed to create environmentaly friendly village (KRL).

However, in Sampora Village, Cibinong, Bogor Regency, waste is still a serious problem. KRL was not operated optimally. Garbages were still dumped into the rivers and the road. People are lack of understanding on how to manage and utilize waste, equipment and waste 
bank.

Therefore, knowledge, training, and assistance in waste management are necessity. In line with the program of sorting waste from home, the activities involve empowering of housewives as people who do most of their activities at home. The method used for this activities were sharing knowledge on how to sort household waste, managing waste with $3 R$ (Reuse, Reduce, Recycle) and maximizing a waste bank. Further, a composter was also prepared to compost organic waste. The results are housewives felt more knowledgeable and willing to sort waste from home.

Key Words: Household Waste, 3R (Reuse, Reduce, Recycle), Housewives Empowerment

\section{PENDAHULUAN}

Sampah tidak pernah lepas dari kehidupan masyarakat. Sampai saat ini bahkan sampah telah memberikan banyak dampak negatif dalam kehidupan masyarakat seperti banjir, polusi, sampai perubahan ekosistem. Padahal hal ini terjadi karena sampah yang dihasilkan oleh masyarakat sendiri tidak dikelola dengan baik. Kementerian Lingkungan Hidup dan Kehutanan (KLHK) menyatakan bahwa di Indonesia, sampah yang dihasilkan secara nasional sebanyak 175.000 ton sehari atau sekitar 64 juta ton per tahun dengan asumsi setiap orang menghasilkan sampah 0,7 kg sehari (Baqirah, 2019) Hal senada tidak hanya terjadi di skala nasional, baru-baru ini Bupati Kabupaten Bogor menyatakan bahwa Kabupaten Bogor darurat sampah. Di Kabupaten Bogor sampah yang dihasilkan sebesar 2.850 ton per hari, tetapi hanya 600-700 ton sampah yang dapat diangkut sehingga sisanya masih menumpuk di Tempat Pembuangan Akhir (TPA) (Ikhsan, 2019). Oleh karena itu pemerintah telah menggalakan berbagai cara dan usaha untuk menangani masalah sampah ini. Berikut adalah data produksi sampah di beberapa kota besar di Indonesia tahun 2016-2017 berdasarkan hasil data dari Badan Pusat Statistik 2018.

Tabel 1. Produksi Sampah Beberapa Kota Besar di Indonesia

\begin{tabular}{|c|c|c|c|c|c|c|}
\hline \multirow[t]{2}{*}{ Kota } & \multicolumn{2}{|c|}{$\begin{array}{l}\text { Perkiraan Produksi } \\
\text { Per Hari }\left(\mathrm{m}^{3}\right) \text { (Ton) }\end{array}$} & \multicolumn{2}{|c|}{$\begin{array}{r}\text { Volume Sampah } \\
\text { Terangkut } \\
\text { Per Hari }\left(\mathrm{m}^{3)} \text { (Ton) }\right.\end{array}$} & \multicolumn{2}{|c|}{$\begin{array}{c}\text { Persentase } \\
\text { Sampah } \\
\text { Terangkut }\end{array}$} \\
\hline & 2016 & 2017 & 2016 & 2017 & 2016 & 2017 \\
\hline Surabaya & $9.710,61$ & $9.896,78$ & $5.237,70$ & $5.427,45$ & 53,93 & 54,84 \\
\hline $\begin{array}{l}\text { DKI } \\
\text { Jakarta }\end{array}$ & $7.099,08$ & $7.164,53$ & $6.016,30$ & $6.872,18$ & 84,75 & 95,92 \\
\hline Makasar & $5.931,40$ & $6.485,65$ & $5.623,61$ & $6.163,42$ & 94,81 & 95,03 \\
\hline Semarang & $5.080,51$ & $5.163,72$ & $4.445,00$ & $5.544,00$ & 87,49 & 88,00 \\
\hline Denpasar & $3.719,00$ & $3.657,20$ & $3.625,00$ & $3.276,55$ & 97,47 & 89,59 \\
\hline
\end{tabular}

Sumber: Statistik Lingkungan Hidup Indonesia, 2018.

\section{Menurut Rosa Vivien Ratnawati, Direktur Jenderal} Pengelolaan Limbah, Sampah, dan Bahan Beracun Berbahaya (PSLB3) KLHK, dari komposisi sampah yang dihasilkan, 50\% sampah adalah organik yaitu berupa sisa makanan dan sisa tumbuhan, $15 \%$ berupa sampah plastik, dan 10\% berupa sampah kertas. Tidak hanya itu, Rosa Vivien juga mengemukakan bahwa dilihat dari sumbernya, sampah ini $48 \%$ bersumber dari sampah rumah, $24 \%$ dari pasar-pasar tradisional, dan sekitar 9\% dari sektor komersial. 
Sedangkan sisanya berasal dari fasilitas publik seperti sekolah, kantor, jalan dan sebagainya. Berdasarkan kondisi inilah, maka KLHK meluncurkan sebuah program Gerakan Nasional Pilah Sampah dari Rumah pada tanggal 15 September 2019 sebagai lanjutan dari program sebelumnya yaitu Gerakan Minim Sampah yang secara masif mulai dilakukan masyarakat (PSLB3, 2019). Harapannya dengan adanya gerakan ini, pengelolaan sampah di hilir terbantu karena sampah telah dipilah dan dikendalikan dari sumbernya yaitu rumah sebagai unit terkecil dari masyarakat.

Pemerintah di daerah sebenarnya banyak yang telah memiliki program yang sejalan dengan program pemerintah pusat. Kabupaten Bogor misalnya telah memiliki program Bogor Kabupatenku Green and Clean (Radar Bogor, 2018). Program tahunan ini diselenggarakan untuk memilih daerah atau kampung terbaik dalam pengelolaan sampah, penataan lingkungan dengan 3R, dan penghijauan lingkungan termasuk lingkungan adiwiyata. Sehingga dengan adanya program yang terpadu ini akan menciptakan kampung-kampung yang ramah lingkungan. Sampai saat ini Kabupaten Bogor telah menganugerahi beberapa Kampung Ramah Lingkungan (KRL) di antaranya yang termasuk 10 terbaik KRL pemula 2018 adalah KRL Panineungan Kelurahan Ciriung, KRL Berkah Sehati Kelurahan Karadenan, KRL Sugutamu Ceria Kelurahan Pabuaran, KRL Ecovillage bersama Desa Citeko, KRL Gunung Leutik Hijau Berseri Desa Kiarasari,
KRL Cobaan Desa Gunung Geulis, KRL RW 09 Kelurahan Puspasari, KRL Warga Saluyu Desa Cibatok, KRL Nanas Desa Kranggan, dan KRL RW 12 Desa Cileungsi Kidul (Sadili, 2018).

Untuk ikut berkontribusi dalam menciptakan lingkungan yang dapat dihuni dengan aman dan nyaman, Kampung Sampora yang terletak di Kelurahan Cibinong, turut serta berpartisipasi dalam program pemerintah kabupaten BKGC. Para tokoh masyarakat telah membentuk susunan organisasi KRL begitu juga orang-orang yang akan terlibat dalam kepengurusan organisasi KRL yang bernama Sampora Resik. Kepengurusan KRL Sampora Resik terdiri dari penanggung jawab, ketua, wakil ketua, seksi pemelihara drainase, bantaran kali, dan sanitasi, seksi pengelolaan sampah, edukasi lingkungan, dan 3R, seksi penanaman dan perawatan Toga, seksi penghijauan, perawatan fasilitas umum dan fasilitas sosial. Berikut adalah aktivitas awal yang telah dilaksanakan Kampung Sampora dalam menghadapi BKGC 2019.

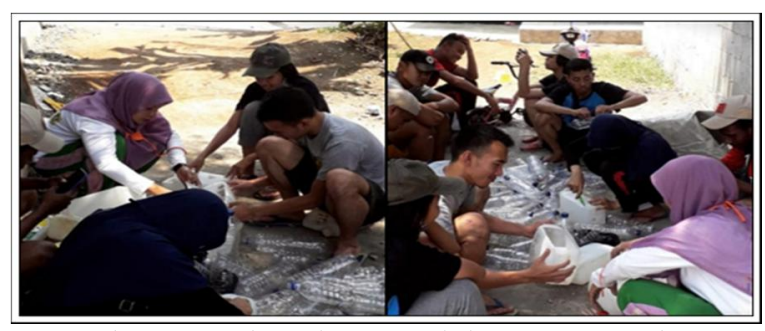

Gambar 1 Pembersihan Botol dan Barang Bekas

KRL Sampora Resik yang dibentuk bulan Februari 2019, telah lolos verifikasi tahap I. Pemetaan target dan strategi telah dibuat tetapi belum semua berjalan dengan baik. Bahkan meskipun Kampung Sampora telah memiliki KRL tetapi 
masalah sampah masih menjadi masalah yang serius. Masyarakat belum sepenuhnya paham dan sadar mengenai sampah dan akibat dari sampah yang tidak dikelola dengan baik. Sampah masih banyak yang dibuang ke sungai, kali, parit, bahkan di jalan.

Di antara kendala yang dihadapi dalam pengelolaan sampah di Kampung Sampora juga termasuk belum dipahaminya dasar pengelolaan sampah yang diawali dengan sampah yang dipilah. Kedua belum adanya pengetahuan mengenai pemanfaatan sampah menjadi produk yang bermanfaat seperti membuat sampah organik menjadi pupuk organik, ketiga kurangnya peralatan untuk pengelolaan dan pemanfaatan sampah, penataan lingkungan dan penghijauan. Dan terakhir adalah belum terbentuknya lembaga untuk menyalurkan hasil pengelolaan dan pengendalian sampah seperti bank sampah. Berikut adalah pemetaan awal target dan strategi Sampora Resik dalam membangun KRL di Kampung Sampora.

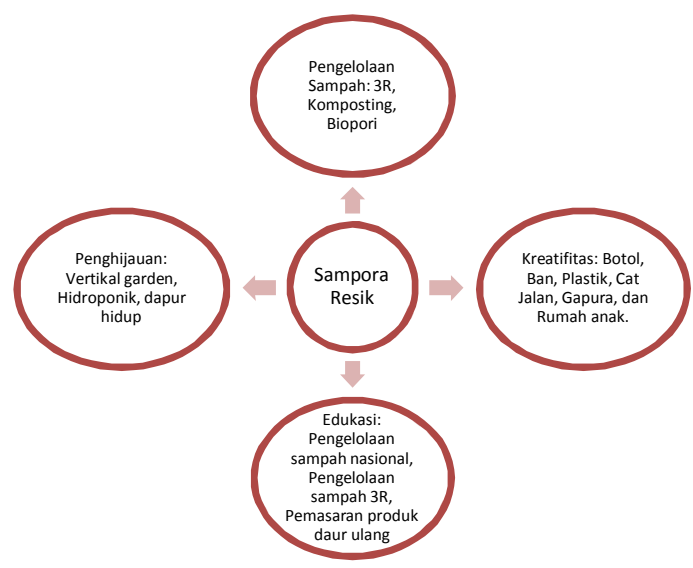

Gambar 2. Target \& Strategi KRL Sampora Resik
Berdasarkan kondisi ini, maka kegiatan pengabdian kepada masyarakat dilakukan untuk memberikan penyuluhan, pelatihan, dan pendampingan terhadap warga masyarakat Kampung Sampora Kelurahan Cibinong. Fokus kegiatan ini adalah pilah sampah rumah karena sebagian besar sampah bersumber dari rumah tangga. Kemudian sebagai peserta kegiatan dipilih ibu rumah tangga sebagai representatif dari masyarakat, karena di rumah yang paling banyak berperan dalam mengatur rumah tangga adalah ibu. Bahkan di rumah tangga, umumnya ibu merupakan perempuan yang paling banyak beraktifitas, sehingga ibu rumah tangga juga memiliki peran strategis dalam menanamkan pemahaman mengenai pengelolaan sampah dari rumah terhadap keluarganya. Menurut penelitian yang dilakukan oleh (Darmawan \& Fatchiya, 2018), pendapatan yang diperoleh rumah tangga dan penyuluhan mengenai lingkungan mempengaruhi perilaku ibu rumah tangga dalam mengelola sampah rumah tangga khususnya aspek kognitif, afektif, dan tindakan.

Oleh karena itu solusi yang ditawarkan di Kampung Sampora, pertama adalah diadakan sebuah kegiatan sharing ilmu melalui penyuluhan mengenai cara pemilahan sampah rumah tangga. Kedua sharing ilmu mengenai pengelolaan dan pemanfaatan sampah dengan berbasis 3R (Reduce, Reuse, Recycle) juga melalui kegiatan penyuluhan.

Ketiga, memperkenalkan cara pembuatan komposter sederhana yang dapat dilakukan oleh ibu rumah tangga di rumah. Dan terakhir yaitu sharing 
pengalaman mengenai pembentukan bank sampah sebagai wadah untuk menampung hasil dari pemilahan dan pengelolaan sampah. Seperti yang telah dilakukan warga Ciharashas Kelurahan Mulyaharja Kota Bogor yang memberdayakan masyarakat untuk menghidupkan kembali bank sampah sebagai wadah untuk menampung hasil dari pilah limbah rumah tangga (Listyandini et al., 2018). Sedangkan untuk peningkatan pengetahuan dan pendampingan penataan lingkungan dan penghijauan lingkungan termasuk lingkungan adiwiyata akan dilakukan oleh Dinas Lingkungan Hidup (DLH) Kabupaten Bogor.

\section{PERMASALAHAN MITRA}

Melalui observasi lapangan dan wawancara awal dengan penggiat dan Ketua KRL Sampora Resik, Bapak Pulung Suhardiman, dirumuskan beberapa point yang menjadi permasalahan utama, yaitu:

1. Masyarakat Kampung Sampora belum memiliki pengetahuan dasar mengenai pemilahan sampah. Pada umumnya sampah rumah tangga masih menggunakan sistem lama yaitu dikumpulkan, diangkut, kemudian dibuang atau dibakar. Padahal pemerintah sudah memperkenalkan sistem baru untuk pengelolaan sampah rumah yaitu pemilahan sampah organik, anorganik, dan residu. Untuk sampah organik dapat dijadikan kompos, sedangkan sampah anorganik dapat diperlakukan 3R yaitu reduce, reuse, dan recycle, atau ditabung di bank sampah. Sementara sampah yang sudah tidak dapat dikelola dapat dibuang ke TPA. Kalau gerakan ini berjalan secara masif, bukan tidak mungkin sampah di TPA akan berkurang karena sampah telah dikendalikan dari sumber terbesarnya yaitu rumah. Oleh karena itu diperlukan adanya kegiatan sharing mengenai cara dan dasar pemilahan sampah dari rumah melalui penyuluhan.

2. Masyarakat Kampung Sampora, belum memiliki banyak pengetahuan dan pengalaman dalam memanfaatkan sampah hasil dari pemilahan di rumah. Padahal sampah setelah dipilah memiliki nilai jual meski tidak direuse atau di-recycle. Selain sampah pilah dapat langsung mendatangkan penghasilan tambahan atau disedekahkan ke pengepul sampah, sampah ini dapat di-reuse atau di-recycle menjadi kompos atau produk lain yang bermanfaat seperti produk bernilai jual. Dengan demikian, masyarakat, khususnya ibu rumah tangga memerlukan suatu sharing pengetahuan melalui penyuluhan untuk membuka wawasan mereka mengenai pemanfaatan sampah.

3. Masyarakat Kampung Sampora terkendala peralatan seperti komposter sehingga setelah kegiatan penyuluhan untuk membuka wawasan ibu rumah tangga, akan diperkenalkan juga pembuatan komposter sederhana sebagai percontohan. Komposter ini harapannya dapat digunakan atau dicontoh di rumah-rumah dengan ibu rumah tangga atau 
anggota keluarga lainnya sebagai pelaku.

4. Masyarakat Kampung Sampora belum memiliki bank sampah di lingkungan masyarakatnya sebagai wadah untuk menampung dan menyalurkan sampah hasil pilah di rumah. Bank sampah menurut Statistik Lingkungan Hidup Indonesia (2018) adalah suatu tempat yang digunakan untuk mengumpulkan sampah yang sudah dikelompokkan. Hasil dari pengumpulan sampah yang sudah dikelompokkan ini kemudian disetor ke pengepul sampah. Bank sampah ini dikelola dengan sistem seperti perbankan dengan adanya petugas yang mencatat penyetoran sampah dari warga yang dianggap sebagai nasabah. Sampah yang disetor kemudian ditimbang dan dihargai setelah itu dicatat di pembukuan. Oleh karena itu, PkM akan melakukan sharing pengalaman mendirikan bank sampah dan pendampingan setelah bank sampah ini terbentuk supaya dapat beroperasi secara optimal.

\section{METODE DAN PELAKSANAAN}

Kegiatan ini dimulai dengan melakukan observasi awal mengenai program pemberdayaan perempuan melalui pengelolaan sampah rumah yang ada di Kampung Sempora. Observasi dilakukan untuk mengetahui lebih jelas masalah yang ada di lapangan dengan menggunakan metode pengamatan, wawancara dan dokumentasi. Observasi awal juga digunakan untuk mengetahui seberapa besar pengetahuan masyarakat mengenai pengelolaan sampah disana. Berikut beberapa kegiatan yang dilakukan di awal pelaksanaan kegiatan.

1. Observasi/Pengamatan

Pengumpulan data melalui observasi bertujuan untuk memperoleh data atau informasi agar lebih lengkap dan rinci dalam menggali informasi tentang kegiatan perencanaan, pelaksaaan dan evaluasi program pemberdayaan perempuan melalui pengelolaan sampah di Kampung Sampora sebagai usaha memberdayakan perempuan khususnya ibu rumah tangga yang memiliki peran penting dalam keluarga.

\section{Wawancara}

Wawancara dilakukan kepada pengelola atau pengurus, narasumber, anggota maupun warga masyarakat lingkungan sekitar. Melalui wawancara diharapkan informasi dapat diperoleh terkait dengan penyelenggaraan programprogram yang telah berjalan di masyarakat Kampung Sampora. Melalui wawancara dengan salah satu penggiat di Lingkungan Kampung Sampora juga didapat informasi mengenai pemberdayaan perempuan dalam pengelolaan sampah rumah di Lingkungan Kampung Sampora yang diharapkan terkoordinir oleh KRL Sampora Resik.

\section{Dokumentasi}

Dokumentasi bertujuan untuk melengkapi data dan hasil dari pelaksanaan pengabdian termasuk pada saat survey awal, pelaksanaan kegiatan, dan untuk kepentingan 
pelaporan. Dokumentasi ini dapat berupa foto termasuk berita-berita acara yang telah disetujui dan sepengetahuan dari dua belah pihak.

Berdasarkan hasil pembicaraan dengan tokoh masyarakat Kampung Sampora, Kelurahan Cibinong, Kampung Sampora memiliki 4 RW dan 18 RT dengan rata-rata 100 kepala keluarga per RT. Sesuai dengan kondisi permasalahan dan target kegiatan, peserta penyuluhan adalah ibu rumah tangga yang memiliki peran strategis dalam menanamkan pemahaman pilah sampah dari rumah di keluarganya. Oleh karena itu, target peserta ditentukan setidaknya 20 sampai 30 ibu rumah tangga proporsional mewakili RW-nya masing-masing. Berikut adalah metode dan pelaksanaan kegiatan, dalam pengabdian ini.

Penyuluhan Mengenai Pilah Sampah Rumah

Kegiatan ini bertujuan untuk sharing ilmu dan membuka wawasan mengenai bagaimana memilah sampah dari rumah yang bisa dilakukan oleh seluruh anggota keluarga melalui pemahaman yang ditanamkan oleh ibu sebagai agen perubahan. Kegiatan ini dilakukan di Aula Majlis Taklim Al Amanah Kampung Sampora Kelurahan Cibinong. Penyuluhan dilakukan selama 2 jam penuh (pukul 13.00 15.00). Penyuluhan ini juga dilakukan melalui tatap muka dua arah antara tutor dengan audiens dan dengan menjaga protokol kesehatan yaitu memakai masker dan menerapkan social distancing.

Sebagai alat bantu, tutor menggunakan infokus, laptop, materi PPT, dan alat peraga lain seperti sedotan yang terbuat dari stainless. Kemudian dalam setiap kegiatan ini juga dilibatkan dua mahasiswa untuk membantu mengatur kelancaran acara.

\section{Penyuluhan Pengelolaan Sampah rumah}

Sebagai kegiatan lanjutan dari penyuluhan pilah sampah rumah dari rumah, kegiatan kedua ini bertujuan untuk sharing ilmu dan membuka wawasan mengenai bagaimana mengelola sampah setelah sampah dipilah dari rumah. Kegiatan pengelolaan ini menggunakan konsep 3R yaitu Reuse, Reduce, Recycle. Sesi penyuluhan diarahkan untuk memberikan materi mengenai pengelolaan sampah organik, anorganik, dan residu. Kemudian setelah jenis sampah dikelompokan, selanjutnya diberikan wawasan mengenai pemanfaatan lebih lanjut jenis-jenis sampah ini. Sebagai contoh sampah organik dapat dimanfaatkan untuk menjadi kompos sedangkan sampah anorganik bisa dibuat menjadi produk yang bermanfaat dan menambah penghasilan keluarga.

Kegiatan ini juga bertempat di Aula Majlis Taklim Al Amanah Kampung Sampora Kelurahan Cibinong. Penyuluhan masih sama dilakukan selama 2 jam penuh (pukul 13.00 - 15.00) dengan tatap muka dan menerapkan protokol kesehatan serta social distancing. Posisi audiens membentuk huruf U dan penyampaian materi diawali dengan ice breaking. Bahasa yang digunakan sederhana dan umum digunakan para ibu sehari-hari. Sebagai alat bantu, tutor menggunakan infokus, laptop, 
materi PPT, dan alat peraga lain seperti ecobrick.

\section{Pembuatan Komposter}

Kegiatan selanjutnya adalah peragaan pembuatan kompos dan komposter. Kegiatan ini bertujuan untuk sharing ilmu dan membuka wawasan mengenai bagaimana memanfaatkan sampah organik menjadi kompos. Pembuatan kompos ini memerlukan alat yang dinamakan komposter. Dalam pertemuan ketiga ini komposter sederhana dibuat dengan disesuaikan dengan kebutuhan dan kemudahan penggunaan sehingga siapa saja dapat menggunakan komposter ini. Ada 4 komposter yang dibuar sesuai dengan jumlah RW. Harapannya ke depan warga dapat membuat komposter sendiri sesuai dengan kebutuhan kapasitas di rumah masing-masing.

Kegiatan ini dilakukan di Aula Majlis Taklim Al Amanah Kampung Sampora Kelurahan Cibinong dari pukul 13.00 sampai 15.00. Kegiatan ini juga dilakukan dengan menjaga protokol kesehatan dan social distancing. Selanjutnya komposter yang telah dibuat diserahkan kepada warga untuk digunakan.

\section{Sharing dan Pendampingan Bank Sampah}

Kegiatan terakhir dari rangkaian program pemberdayaan perempuan untuk pilah sampah dari rumah adalah sharing ilmu mengenai urgensi pembentukan bank sampah dan mengoptimalkan manfaat adanya bank sampah ini bagi masyarakat. Kegiatan ini masih dilakukan di Aula Majlis Taklim Al Amanah Kampung Sampora Kelurahan Cibinong dari pukul 13.00 - 15.00 dengan menjaga protokol dan menerapkan social distancing.

Sesi penyuluhan diarahkan untuk sharing materi mengenai pemanfaatan sampah yang dapat menambah penghasilan keluarga. Bank sampah berfungsi untuk menampung hasil pilah sampah rumah tangga yang telah dilakukan.

\section{HASIL DAN LUARAN}

Sampah yang masih menjadi sumber masalah dalam kehidupan masyarakat sehari-hari semakin hari semakin terus bertambah. Meski banyak program pemerintah yang telah diluncurkan namun tidak lantas membuat masalah sampah menjadi lebih tertanggulangi dengan bijaksana. Pada kenyataannya masyarakat semakin tidak arif dalam menjalankan segala aktivitasnya sehingga lebih berdampak pada timbulan sampah yang semakin meningkat.

Para tokoh masyarakat di Kampung Sampora, Kelurahan Cibinong sangat memahami kondisi ini. Mereka mencoba merubah kebiasaan masyarakat dalam menangani sampah yang masih menggunakan pola lama yaitu dikumpulkan, diangkut, untuk kemudian dibuang atau dibakar dengan pola baru yaitu dipilah, kemudian di reuse, reduce, dan recycle baru residunya dibuang. Sebagai langkah awal, di Kampung Sampora telah dibentuk Kampung Ramah Lingkungan. Namun demikian kondisi sampah di masyarakat masih menjadi masalah yang serius. Oleh karena itu sejalan dengan program pemerintah Gerakan Pilah Sampah dari Rumah dan dalam mendukung program KRL Sampora 
Resik yang telah dibentuk di Kampung Sampora, pengabdi memutuskan untuk mengadakan penyuluhan, pelatihan, dan pendampingan mengenai pilah sampah dari rumah dan bagaimana pengelolaannya. Para peserta yang dilibatkan dalam kegiatan ini adalah para ibu yang memiliki peran penting tidak hanya sebagai orang yang paling banyak beraktifitas di rumah tetapi juga memiliki peran strategis menanamkan pemahaman dan kesadaran anggota keluarga lainnya dalam memilah dan mengelola sampah rumah. Pengabdi juga kemudian memperagakan alat untuk membuat komposter sederhana dan sharing bagaimana mengoptimalkan peran bank sampah.

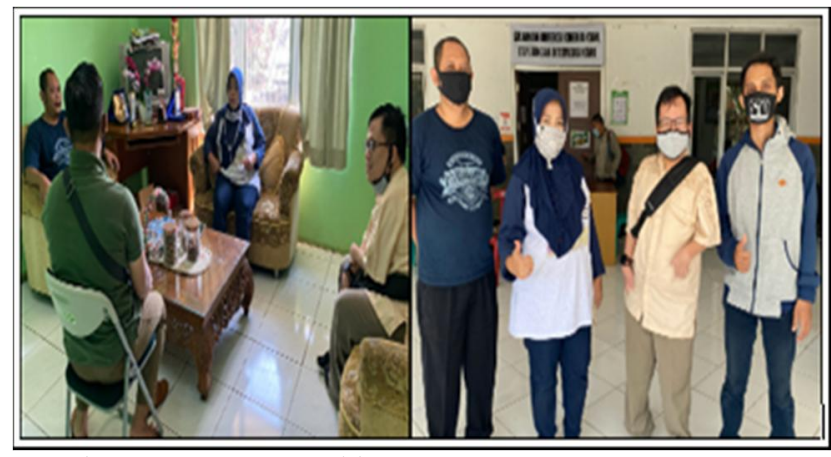

Gambar 3. Survey Awal ke Kampung Sampora

Pelaksanaan penyuluhan mengenai pengelolaan sampah rumah dengan melibatkan ibu rumah tangga sebagai agen perubahan dilakukan seminggu sekali setiap hari Senin dari pukul 13.00 sampai 15.00. Penentuan jam pertemuan ini dilakukan dengan memepertimbangkan umumnya waktu luang para ibu rumah tangga karena kalau pagi atau sore hari para ibu biasanya memiliki kesibukan dalam menyiapkan keperluan keluarganya masing- masing.

Setiap sesi penyuluhan, pelatihan, dan sharing dilaksanakan dengan menerapkan protokol kesehatan dan social distancing meskipun kegiatan dilakukan dengan tatap muka. Posisi tempat duduk audiens juga diatur dengan membentuk huruf $U$ supaya terkesan santai dan tidak menggurui. Penyampaian materi diawali dengan ice breaking dan disisipkan dengan permainanpermainan dengan pertanyaan supaya audiens labih fokus dan kegiatan menjadi menarik. Bahasa yang digunakan adalah bahasa sederhana dan umum digunakan para ibu sehari-hari.

Sesi pertama diarahkan untuk membuka wawasan para ibu dengan memberikan materi mengenai sampah, jenis sampah, dan bagaimana memilah sampah dari rumah. Kemudian sesi ini juga menjadi sesi penting dalam menanamkan ibu sebagai agen perubahan dalam menanamkan pemahaman di keluarga mengenai pentingnya memilah sampah dari rumah. Karena peran strategis inilah para ibu rumah tangga merupakan sosok penting dalam keluarga untuk membangun karakter dan kesadaran anggota keluarganya mengenai pilah sampah rumah dan pengelolaan sampah. Hasil dari pertemuan ini para ibu menjadi semangat dan bertambah wawasan mengenai sampah rumah. Para ibu juga terinspirasi dengan pola pengelolaan sampah baru terutama untuk konsep 3R (Reuse, Reduce, Recycle). Pertemuan pertama ini juga diapresiasi oleh pemerintah setempat yaitu dihadiri oleh Lurah 
Cibinong dan Kasi Ekonomi dan Pembangunan.

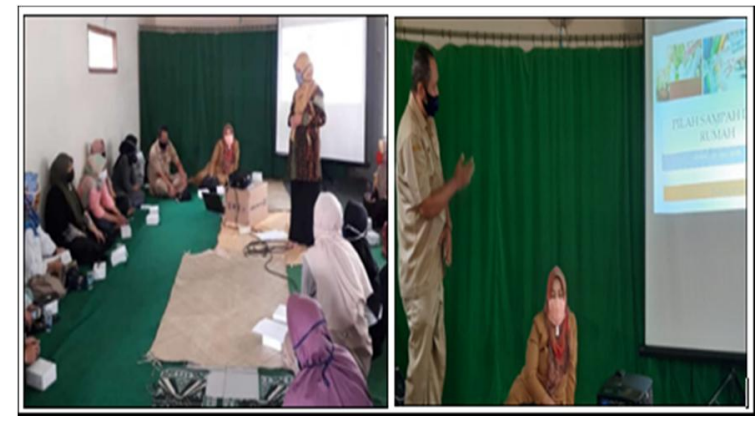

Gambar 4. Penyuluhan Pilah Sampah Rumah

Sesi selanjutnya diarahkan untuk membuka wawasan bahwa sampah dapat mendatangkan manfaat lagi bagi keluarga. Sampah organik dapat dibuat menjadi kompos dan digunakan untuk menyuburkan tanaman yang dipelihara sendiri di rumah. Kemudian sampah anorganik dapat dimanfaatkan menjadi produk lain yang bermanfaat bahkan bisa mendatangkan penghasilan tambahan bagi keluarga. Produk yang dikenalkan dengan memanfaatkan sampah di kegiatan ini adalah pembuatan ecobrick dan membuat gantungan kunci berbentuk ikan dari bungkus plastik bekas sabun dan minyak. Para ibu rumah tangga juga dianjurkan untuk tidak membuang minyak jelantah karena ternyata minyak jelantah dapat dijual dengan harga yang kompetitif. Hasilnya peserta lebih paham bagaimana memanfaatkan sampah dan sangat tertarik untuk mengelolanya menjadi produk yang menambah penghasilan keluarga. Mereka berjanji untuk minyak jelantah pun tidak lagi dibuang tetapi akan dikumpulkan untuk kemudian dijual.

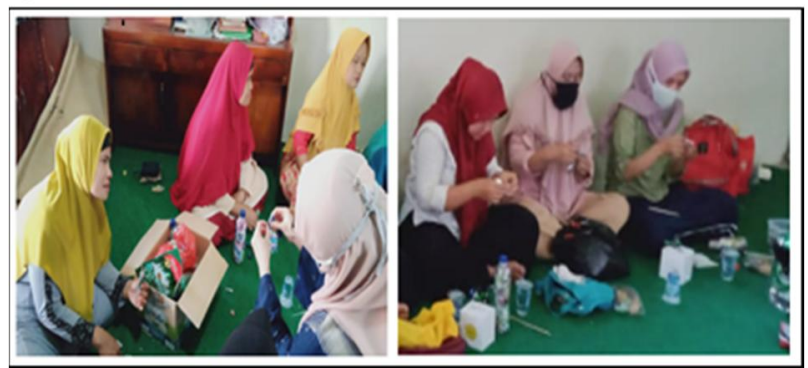

Gambar 5. Peragaan Ecobrick dan Kerajinan Ikan dari Sampah

Untuk melengkapi pengetahuan mengenai penanganan hasil dari pilah sampah rumah, peserta dibekali dengan pengetahuan mengenai cara membuat komposter sederhana. Komposter adalah alat yang digunakan untuk menghasilkan kompos dari sampah organik. Pada sesi ini pengabdi membuatkan alat komposter yang mudah digunakan oleh siapapun termasuk ibu rumah tangga. Sebagai luaran alat ini kemudian dipersiapkan sebanyak 4 buah sesuai dengan jumlah RW di Kampung Sampora. Harapannya para warga terinspirasi untuk membuat alat ini di rumahnya masing-masing karena sederhana dan tidak mahal. Manfaat dari komposter sederhana ini dapat digunakan untuk membuat kompos dengan cara yang mudah.

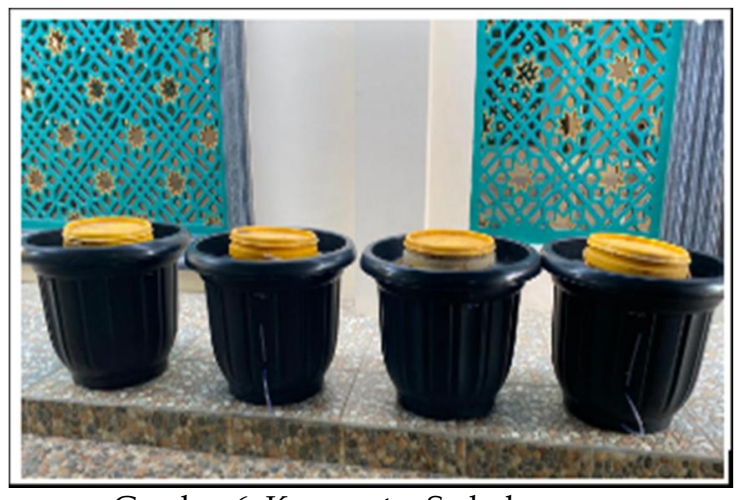

Gambar 6. Komposter Sederhana

Terakhir untuk pengenalan bank sampah, pengabdi 
mengarahkan sesi ini untuk membuka wawasan dan juga memaksimalkan peran bank sampah. Manfaat dari adanya bank sampah ini adalah menampung hasil pilah sampah rumah tangga. Hasilnya, bank sampah sudah terbentuk tetapi masyarakat belum optimal memanfaatkan keberadaan bank sampah ini. Sehingga perlu peningkatan pemahaman mengenai bank sampah ini sebagai wadah yang menyalurkan hasil pilah sampah dengan sistem perbankan. Operasional bank sampah ini berjalan menyerupai bank komersial pada umumnya, ada yang namanya nasabah, penyetoran sampah pilah, dan pembukuan setoran di buku bank sampah.

\section{SIMPULAN DAN SARAN}

Pada dasarnya kegiatan pengabdian untuk memberdayakan perempuan dalam pilah sampah rumah di Kampung Sampora Kelurahan Cibinong telah dilaksanakan dan berjalan dengan baik. Masyarakat kampung sampora sangat antusias mengikuti pelaksanaan kegiatan ini, karena selain dapat memperkaya ilmu untuk mengoptimalkan kampung ramah lingkungan, juga menambah wawasan mengenai bagaimana sampah dapat dipilah dari rumah.

Peran ibu rumah tangga sebagai agen perubahan memiliki kontribusi strategis dalam membangun karakter dan pemahaman anggota keluarganya mengenai pilah sampah dari rumah dan pengelolaan sampah dari rumah. Kemudian wawasan yang mereka dapatkan juga bermanfaat memberikan tambahan penghasilan keluarga dari pemanfaatan sampah yang sudah dipilah. Harapannya wawasan yang didapat oleh para ibu rumah tangga dapat memberikan pengaruh positif tidak hanya bagi keluarganya masingmasing tetapi juga bagi lingkungan masyarakat sekitarnya.

Saran untuk masyarakat kampung sampora kelurahan cibinong, kegiatan ini dapat dilaksanakan secara regular dan berlanjut terus menerus tidak hanya terbatas dalam kegiatan PKM ini, mengingat tingginya kebutuhan masyarakat terhadap pemahaman pemilahan sampah rumah tangga.

\section{UCAPAN TERIMA KASIH}

Dengan terselesaikannya
artikel ini, tim pengabdi
mengucapkan terima kasih kepada
Lembaga Penelitian dan Pengabdian
Masyarakat (LPPM) Universitas
Pakuan atas bantuan dana yang
diberikan dalam pengabdian ini.
Selain itu, tim pengabdi juga
mengucapkan terima kasih kepada
seluruh tim yang terlibat dalam
penyelesaian Pengabdian Kepada
Masyaratat (PKM) ini.

\section{REFERENSI}

Baqirah, N. F. A. B. (2019). Timbulan

Sampah Nasional Capai 64 juta ton

per Tahun - Ekonomi Bisnis.com. 21

Febuari.

https:/ / ekonomi.bisnis.com/read /20190221/99/891611/timbulansampah-nasional-capai-64-jutaton-per-tahun.

Darmawan, R., \& Fatchiya, A. (2018). Analisis Perilaku Ibu Rumah 
Tangga Bantaran Sungai

Citampian dalam Mengelola

Sampah Rumah Tangga. Jurnal

Sains Komunikasi Dan

Pengembangan Masyarakat [JSKPM],

2(4), 431.

https://doi.org/10.29244/jskpm.2 .4.431-440.

Ikhsan, A. (2019). Kabupaten Bogor darurat sampah, bupati terapkan sistem zonasi.

https://regional.kontan.co.id/ne ws/kabupaten-bogor-daruratsampah-bupati-terapkan-sistemzonasi.

Listyandini, R., Aisyah, N., Robby, P. A., \& Kurniawan, D. (2018). Pemanfaatan Bank Sampah untuk Mengelola Limbah Rumah Tangga di Desa Ciharashas Kelurahan Mulyaharja Kota Bogor. Promotor, 1(2), 116-123.

https://doi.org/10.32832/PRO.V1 I2.1597.

PSLB3. (2019). Kabupaten Bogor darurat sampah, bupati terapkan sistem zonasi.

https://regional.kontan.co.id/ne ws/kabupaten-bogor-daruratsampah-bupati-terapkan-sistemzonasi.

Radar Bogor. (2018). Ubah Pola Pikir Kelola Lingkungan | RADAR BOGOR | Berita Bogor Terpercaya. https:/ / www.radarbogor.id/2018 /04/24/ubah-pola-pikir-kelolalingkungan/.

Sadili, H. (2018). 40 Kecamatan Di Kabupaten Bogor Ikuti Gelaran "Bogor Kabupatenku Green and Clean" - kilasbogor.com - Cerdas, Inspiratif, Informatif. https://kilasbogor.com/ragam/40 -kecamatan-di-kabupaten-bogorikuti-gelaran-bogor-kabupatenkugreen-clean/.

Statistik Lingkungan Hidup Indonesia, (2018). Badan Pusat Statistik. https://www.bps.go.id/pressrele ase.html?katsubjek=\&Brs $\% 5 \mathrm{Btgl}$ rilis_ind $\% 5 \mathrm{D}=\& \mathrm{Brs} \% 5 \mathrm{Btahun} \% 5$ $\mathrm{D}=2018 \& \mathrm{t} \mathrm{t} 0=$ Cari 